\title{
The Characteristics and Flexible Scheme of Students' Art Troupes at Higher Vocational and Technical Colleges in China: A Case Study on the Art Troupe at $\mathrm{N}$ Higher Vocational and Technical College
}

\author{
Huo Sheng ${ }^{1}$, Xiuqing Fang ${ }^{2}$ \\ ${ }^{1}$ Ph. D. Course, Arts Managemen, Gachon University, Korea, panpansheng321@gmail.com \\ ${ }^{2}$ Adjunct Professor, Arts Managemen, Gachon University, Korea, bangsk@gachon.ac.kr
}

Corresponding author: Xiuqing Fang

\begin{abstract}
In order to more effectively cultivate creative talent, China's higher education institutions have actively offered art education courses that can optimize their course system and have also built art troupes for their students. This paper mainly aims to promote equality in China's higher arts education system, narrow the development gap between student art troupes at undergraduate schools and those of vocational and technical colleges in China's higher education system, and explore the characteristics and flexible schemes of China's higher vocational and technical colleges' students' art troupes. In this line, the students' art troupe at N Higher Vocational and Technical College in China was used as a case study to analyze the four dimensions of the management system, student structure, faculty strength and activity scope of the students' art troupe at this school based on investigation, observation and interview. The research results showed that in China's higher vocational and technical colleges has the following four characteristics. First, Management has begun to develop but is not systematic. Second, Enrollment quality is low and talent is scarce. Third, The faculty is limited and has high turnover. Fourth, There is a diversified campus culture but its branding is not distinct. Based on these characteristics, this paper presents the flexible scheme.
\end{abstract}

Keywords: China's Higher Vocational and Technical College, College Students' Art Troupe, Characteristics of Art Troupes, Flexible Schemes

\section{Introduction}

During the 19th century, it was generally believed that science and technology was the main goal for achieving social development and promoting humanistic education. As technology has continued to progress, people have gradually learned that cultivating innovative talent is the primary aspect of technological development. They also discovered that art, humanities, and science characterized by abstract concepts, freedom and innovation are important elements of cultivating creative talent. In order to more effectively cultivate creative talent, higher education institutions have actively offered art education courses that can optimize their course system and have also built art troupes for their students.

Several four-year undergraduate college students' art troupes have had outstanding achievements in China. For example, Tsinghua University's students' art troupe was invited to visit Greece, the United States, Great Britain, Ireland, Australia, Thailand and other countries for cultural exchanges and also hosted special performances[1]. Recently, Peking University's students' art troupe has visited several

Received: August 20, 2020; $1^{\text {st }}$ Review Result: October 03, 2020; $2^{\text {nd }}$ Review Result: November 20, 2020 Accepted: December 28, 2020 
universities for exchange programs, visits, and special performances, including Stanford University, the University of Maryland, Cornell University, Columbia University, Yale University and Moscow State University. The government of Vienna invited Nanjing University's students' art troupe to performance in the Golden Hall and has gone on exchange visits to and hosted special performances in Great Britain, France and Germany[2]. Interviews with art tutors from more than five Chinese top 20 higher vocational and technical colleges, including the Jiangsu Vocational Institute of Architectural Technology, Jiangsu College of Engineering and Technology and Shandong Zibo Vocational Institute indicated that none of the students' art troupes from these colleges has had experience with participating in international cultural exchanges[3]. Beginning in 2005, the Ministry of Education of the People's Republic of China has sponsored the National University Students' Art Exhibition, which is held once every three years. During the fifth edition of this event, over $90 \%$ of China's higher education institutions in China had participated in it[4]. According to the list of winning teams during that year's event, 590 performance works won an award, while this included only 43 performance works by higher vocational and technical colleges. Both four-year undergraduate institutions and three-year higher vocational and technical colleges are higher education institutions. Although they have different modes of talent cultivation, they share common goals that are intended to cultivate creative talent[4]. The current situation of international exchanges at higher education institutions and award-winning results at the National University Students' Art Exhibition demonstrates that a large gap exists between higher vocational and technical colleges and undergraduate institutions. As a result, there are still deficiencies that must be researched and explored[5].

A literature review of Chinese and overseas research related to art troupes found that most of focused on management of and research on primary and middle school art troupes[6]. It also found that research related to art troupes at higher education institutions was about art organizations, which were groups that students spontaneously formed. The art troupes that this research referred to were those that school departments managed, while students who tested into and were recruited to schools based on their performance on the college entrance examination's test for artistically talented students as well as artistic teams that artistically talented students who were selected from the entire school formed to represent their schools' highest artistic level[7]. These students represented their school when participating in national, provincial, municipal, and regional-level competitions and performances, and differ from ordinary artistic organizations[8]. Moreover, Chinese research about art troupes is mostly focused on troupes from four-year undergraduate educational institutions or research related to art troupes that are used to enhance ideological and political education. There was a limited amount of research about the management of art troupes at higher vocational and technical colleges. In addition, there was no highquality core or dissertations. As a result, the author will focus on higher vocational and technical colleges as a point of innovation to research their students' art troupes[9].

The research object of this paper is the Students' Art Troupe of N Higher Vocational and Technical College. As the art instructor of N Higher Vocational and Technical College, the author personally participated in the instruction and management of the students' art troupe. The author interviewed and exchanged with art instructors of many higher vocational and technical colleges in China in many years of art instruction work and found that, the Students' Art Troupe of N Higher Vocational and Technical College like most students' art troupes of higher vocational and technical colleges, no matter from the mode of art single entrance examination, the establishment of management departments to the setting of hardware facilities are highly similar with four-year undergraduate colleges and universities. However, as students' art troupes of higher vocational and technical colleges, the performances have been no qualitative breakthrough. Therefore, the author takes the Students' Art Troupe of N Higher Vocational and Technical College as the research object, finds out the characteristics of China's higher vocational and technical colleges and presents flexible schemes through the case analysis of the four dimensions, namely, management system, student structure, faculty strength and activity scope. This 
research intends to identify the characteristics of Chinese higher vocational and technical colleges and propose flexible solutions. It also intends to increase the management efficiency of student art troupes at these colleges, increase their work achievements, reduce the distance between these art troupes at these colleges and those at four-year undergraduate educational institutions, and create balance among aesthetic education in Chinese higher education.

\section{Research Method}

In order to directly and efficiently collect the required data, it analyzes the Students' Art Troupe of $\mathrm{N}$ Higher Vocational and Technical College this research. The research methods used in this research include documentary investigation, observation and interview.

About documentary investigation method, it includes the collection and sorting of materials like registration of registered group members, personnel registration of teachers, quarterly meeting reports and annual work summary of N Higher Vocational and Technical College from 2014 to 2019. Although the Students' Art Troupe of N Higher Vocational and Technical College was established in 2008, it did not begin to manage systematically until 2014. So, the collection of documentary investigation materials chooses the internal data from 2014 to 2019.

Observation method is through communication and contact with the college staff and members of the troupe, focusing on personal experience. Because the author has been the art instructor of the college with long-term participation in the management and instruction of the Students' Art Troupe of N Higher Vocational and Technical College, so the author can accurately observe the developments and changes of the Students' Art Troupe of N Higher Vocational and Technical College.

In the interview method, the author interviewed 14 teachers and student leaders in charge of the Students' Art Troupe of N Higher Vocational and Technical College. The interviewees included one department director, six instructors, one general head of the college students' art troupe and six heads of each branch troupe of the college students' art troupe. Because they are the most first-level managers and participants in the college, they are most familiar with the operation of the team and can answer the interview content most accurately. As for the interview content, it mainly centers on the four dimensions of the management system, student structure, teachers and scope of activities. [Table 1] displays the interview contents and questions of the responsible personnel of Students' Art Troupe of N Higher Vocational and Technical College. The way of interview was a semistructured interview, which included not only on-site interview, but also follow-up communication by telephone and email.

[Table 1] The Interview Contents and Questions of the Responsible Personnel of N Higher Vocational and Technical College

\begin{tabular}{|c|c|}
\hline Key points of interview & Interview questions \\
\hline System management & $\begin{array}{l}\text {-Are you satisfied with the existing management system? } \\
\qquad \text { What are the management difficulties? }\end{array}$ \\
\hline Composition of troupe members & $\begin{array}{l}- \text { Are you satisfied with the current composition of troupe members? } \\
\qquad \text { What is the biggest difficulty in teaching? }\end{array}$ \\
\hline faculty strength & $\begin{array}{l}\text { - Are you satisfied with the arrangement of existing teachers in the college? } \\
\text { - Are you willing to be in charge of the students' art troupe for a long time? }\end{array}$ \\
\hline activity scope & $\begin{array}{l}\text { - Are you satisfied with the current activities? } \\
\text { - What kind of activities are you looking forward to? }\end{array}$ \\
\hline
\end{tabular}

The author followed the principle of "triangle verification" in order to improve the reliability and validity of this research. The author mutually confirmed the internal data, observation contents and 
interview contents through the case analysis of documentary investigation, observation and interview method to strengthen the validity and reliability of the data.

\section{A Case Study on the Student' Art Troupe of N Higher Vocational and Technical College}

\subsection{A Summary of the Students' Art Troupe of N Higher Vocational and Technical College}

The students' art troupe of $\mathrm{N}$ higher vocational and technical college comprises five groups (dance group, music instrument group, drama group, reading group and reception team) and is a school-level students' art troupe subordinate to the School Troupe Committee (China's higher vocational and technical colleges refer to three-year college schools in the higher education system of China. College students' art troupes refer to students' art teams which are subordinate to a functional department of the school, represent the highest art level of the school and are composed of students who are good at art, love art and are elected through student art skill assessment at school. Such teams are not clubs organized by students themselves but school-level art teams organized and managed by the school as a whole). Wherein, dance group comprises the street dance group and the folk dance group; the music instrument group comprises the pop band and the national traditional orchestra. The students' art troupe can be dated back to the selection of students' art troupe s of Jiangsu Province in 2008. Through analyzing the change of the management system of the students' art troupe of $\mathrm{N}$ higher vocational and technical college, the development of the Students' Art Troupe is divided into three stages. [Table 2] presents the development history of the Students' Art Troupe of N higher vocational and technical college. There are three stages. The first stage: Foundation of the students' art troupe (2018-2010); Stage II: Trial management of the students' art troupe (2010-2014); Stage III: Systematic development of the students' art troupe (2014-2019).

[Table 2] The Development History of N Higher Vocational and Technical College

\begin{tabular}{|c|c|c|c|}
\hline Stage & Name & Time & Details \\
\hline Stage I & $\begin{array}{c}\text { Early foundation } \\
\text { of students' art } \\
\text { troupe }\end{array}$ & 2008 2010 & $\begin{array}{l}\text { Choir was early founded in } 2008 \text { with an opportunity of Jiangsu provincial } \\
\text { students' art troupe selection, and participated in the selection, and the choir was } \\
\text { awarded a title of good students' art troupe in Jiangsu province. } \mathrm{N} \text { higher } \\
\text { vocational and technical college established college students' art troupe dance, } \\
\text { instrumental music group, comedy troupe, reciting groups, etiquette team. }\end{array}$ \\
\hline Stage II & $\begin{array}{c}\text { Tentative } \\
\text { management of } \\
\text { the students' art } \\
\text { troupe }\end{array}$ & 2010 2014 & $\begin{array}{l}\text { New campus of N higher vocational and technical college was established in } 2010 \text {, } \\
\text { built students' activity center and training venues for the each group of the } \\
\text { students' art troupe, increased the special funds and added the students' art troupe } \\
\text { campus culture activities. }\end{array}$ \\
\hline Stage III & $\begin{array}{c}\text { Systematic } \\
\text { development of } \\
\text { the students' art } \\
\text { troupe }\end{array}$ & 2014 2019 & $\begin{array}{l}\text { Public art teaching and research section, which was established in 2014, started to } \\
\text { expand the team of art tutors. Art education center, which was established in 2016, } \\
\text { will include the public art teaching and research section. Students' art troupe } \\
\text { increased full-time art teachers and futher increased the special funds, and each } \\
\text { group of students' art troupe made some achievements at the provincial and city } \\
\text { competitions and others. }\end{array}$ \\
\hline
\end{tabular}




\subsection{Students' Art Troupe Case Analysis in N Higher Vocational and Technical College}

\subsubsection{Management System}

Currently, the students' art troupe of each higher vocational and technical college in China is subordinate to one functional department of the school. The Students' Art Troupe of N Higher Vocational and Technical College is subordinate to the School Troupe Committee (Art Education Center) of the school. The School Troupe Committee (Art Education Center) is equipped with a public art teaching research office whose Director is the Chief Management Teacher of the Students' Art Troupe. Each group is set with tutors. The Students' Art Troupe is configured with one Chief Director, and each group has one director and one deputy director who are assumed by students. "Are you satisfied with the existing management system?", "What are the management difficulties?" The author asked questions in the interview. 14 interviewees expressed dissatisfaction with the existing system, and they generally believed that the existing management system failed to meet all the aspects covered in the management, and that the difficulties mainly focus on the lack of a good reward and punishment system for excellent students and lazy students. In [Table 3], it shows the initial formulation and the latest revision time of each branch troupe obtained by the author through the management system of each branch troupe of the College Students' Art Troupe. Through the analysis of [Table 3], it can be found that the formulation and revision time of each branch troupe is not the same, there is no unified management system, and each branch troupe presents the phenomenon of self-management. From the analysis of the management code of the six branch troupes, namely, Glee Club Management Code, Dance Troupe Management Code, Instrumental Music Troupe Management Code, Drama Troupe Management Rules, Recitation Troupe Management Code and Reception team Management Code, it is concluded that the regimes are generally unscientific and cover small areas, mainly aiming at the specifications of students' late arrival and early departure and the cleaning rules of the training room. There is no explicit mention of rewards and punishments for troupe members. As for the difficulties of conflict between curriculum and performance generally raised by the interviewees, student leaders generally expressed that when encountering conflicts, they hoped that the instructors would help communicate about adjusting the examination time, and they were unwilling to give up the opportunity to perform; The instructors said that because there was no unified system in the college, the coordination process would cause departmental conflicts, so there was no good solution to such incidents.

[Table 3] Preparation Timetable of Management Regulations of the Students' Art Troupe of N Higher Vocational and Technical College

\begin{tabular}{|c|c|c|c|}
\hline Unit & Quantity & The initial set time & Latest modification time \\
\hline College level & 0 & & \\
\hline Students' art troupe & 0 & & \\
\hline Glee club & 1 & 2008 & 2010 \\
\hline Dance group & 1 & 2008 & 2010 \\
\hline instrumental music troupe & 1 & 2008 & 2014 \\
\hline Drama group & 1 & 2010 & 2016 \\
\hline Reciting team & 1 & 2016 & 2016 \\
\hline Reception team & 1 & 2010 & 2018 \\
\hline
\end{tabular}

In addition, in [Table 4], it displays the Activities Timetable of the Students' Art Troupe of N Higher Vocational and Technical College, which is compiled by the author through sorting the Annual Summary of the College Students' Art Troupe from 2014 to 2019. It recorded the time of the Freshmen Party and the New Year Party in six years in this table. Combined with the analysis of the school calendar, it proves that the time of large-scale activities for six consecutive years conflicted with the mid-term and final examinations. The contents of the table also confirmed the difficulties mentioned by instructors 
and students in the interview that there would be conflicts between curriculum and performance arrangements in large-scale activities, which makes it difficult for students to balance their studies and activities.

[Table 4] Activity Timetable of the Students' Art Troupe of N Higher Vocational and Technical College (2014 2019)

\begin{tabular}{|c|c|c|}
\hline Year & Time of meeting new students party & Time of New Year's party \\
\hline 2014 & October 31 (Friday) & December 29 (Monday), December 30 (Tuesday) \\
\hline 2015 & October 23 (Friday) & December 29 (Tuesday), December 30 (Wednesday) \\
\hline 2016 & October 28 (Friday) & December 29 (Wednesday), December 30 (Thursday) \\
\hline 2017 & November 10 (Friday) & December 29 (Tuesday), December 30 (Wednesday) \\
\hline 2018 & October 19 (Friday) & December 29 (Wednesday), December 30 (Thursday) \\
\hline 2019 & October 25 (Friday) & December 29 (Thursday), December 30 (Friday) \\
\hline
\end{tabular}

\subsubsection{Composition of League Members}

[Table 5] is Composition Table of Students' Art Troupe Members of N Higher Vocational and Technical College from 2014 to 2019, which is sorted and analyzed by the author through the records of Registration of Registered Troupe Members of N Higher Vocational and Technical College from 2014 to 2019, with 284 members enrolled in 2014, 283 in 2015, 292 in 2016, 288 in 2017, 281 in 2018 and 284 in 2019. The instrumental orchestra has only recruited students with basic knowledge of instruments when recruiting members, which is more special. Among other teams, the glee club and dance troupe have the largest number of recruits for six consecutive years, which are the most popular art teams among college students.

[Table 5] Group Member Composition Table of the Students' Art Troupe of N Higher Vocational and Technical College (2014 2019)

\begin{tabular}{|c|c|c|c|c|c|c|}
\hline Year & $\begin{array}{l}2014(284 \\
\text { persons })\end{array}$ & $\begin{array}{c}2015(283 \\
\text { persons })\end{array}$ & $\begin{array}{l}2016(292 \\
\text { persons })\end{array}$ & $\begin{array}{c}2017(288 \\
\text { persons) }\end{array}$ & $\begin{array}{l}2018(281 \\
\text { persons })\end{array}$ & $\begin{array}{c}2019(284 \\
\text { persons) }\end{array}$ \\
\hline Glee Club & 78 & 80 & 78 & 75 & 80 & 75 \\
\hline $\begin{array}{l}\text { Instrumental } \\
\text { Music Troupe }\end{array}$ & 43 & 45 & 45 & 43 & 41 & 41 \\
\hline Dance Troupe & 75 & 75 & 80 & 77 & 75 & 75 \\
\hline Drama Troupe & 43 & 40 & 45 & 43 & 40 & 46 \\
\hline Recitation Group & 22 & 20 & 24 & 25 & 20 & 22 \\
\hline $\begin{array}{l}\text { Reception } \\
\text { Team }\end{array}$ & 23 & 23 & 20 & 25 & 25 & 25 \\
\hline
\end{tabular}

[Table 6] is the Composition Table of the College Students' Art Troupe members' professional competence of N Higher Vocational and Technical College from 2014 to 2019, which includes the number of members who have studied in one year (excluding one year), one to three years (excluding three years), three or more years and who has no professional study experience. In the past six years, the total number of students enrolled by the College Students' Art Troupe ranged from 281 to 292, but the total number of students without professional study was 186 and accounted for $65 \%$ in 2014, 144 and accounted for 50\% in 2015, 165 and accounted for 57\% in 2016, 160 and accounted for 56\% in 2017, 136 and accounted for 48\% in 2018, 137 and accounted for 48\% in 2019, except for $48 \%$ in 2018 and 2019, the others were over 50\%. The Students' Art Troupe of N Higher Vocational and Technical 
College as a college has only three years of schooling, students have a short time in school with only freshman and sophomore two years of study in school, junior needs practice outside the college, and sophomore involves a number of skills examinations, academic pressure becomes greater, so the College Students' Art Troupe is composed of freshmen. Only the head of the college student art troupe, the head and the deputy head of each branch troupe are sophomores, assisting the instructors in the management of the troupe.

[Table 6] Composition of Professional Competence of Members of the Students' Art Troupe of N Higher Vocational and Technical College (2014 2019)

\begin{tabular}{|c|c|c|c|c|c|}
\hline Year & Total number & $\begin{array}{c}\text { Within one year } \\
\text { of professional } \\
\text { study (excluding } \\
\text { one year) }\end{array}$ & $\begin{array}{c}\text { One to three } \\
\text { years of } \\
\text { professional } \\
\text { study } \\
\text { (excluding } \\
\text { three years) }\end{array}$ & $\begin{array}{c}\text { More than } \\
\text { three years of } \\
\text { professional } \\
\text { study }\end{array}$ & $\begin{array}{c}\text { Without professional } \\
\text { study (Proportion of } \\
\text { total number) }\end{array}$ \\
\hline 2014 & 284 & 42 & 44 & 12 & 186 \\
\hline 2015 & 283 & 59 & 55 & 25 & 144 \\
\hline 2016 & 292 & 50 & 39 & 38 & 165 \\
\hline 2017 & 288 & 58 & 24 & 46 & 160 \\
\hline 2018 & 281 & 66 & 29 & 50 & 136 \\
\hline 2019 & 284 & 64 & 29 & 54 & 137 \\
\hline
\end{tabular}

In addition, among the 14 interviewees, the student leaders generally expressed their satisfaction with the troupe member's constitution as for the question "Are you satisfied with the composition of the existing troupe members?". They thought that the troupe members' professional competence was not much different when took as troupe members, the teacher could teach them from the foundation, which was helpful to professional study; the quality of members' professional competence did not have much influence on the troupe management when serving as the student leaders. However, the director of department and the instructors were not satisfied with the composition of the troupe members. Because they had the pressure of performance, the awards and performance effects of the College Students' Art Troupe would affect the income and future development of teachers. They believed that the professional competence of the existing members was relatively weak, which brought great difficulties to the display of works. When asked "What is the biggest difficulty in teaching?" in the interview, the instructors believed that the biggest difficulty was also the weak foundation of the members. Most of the members recruited by the College Students' Art Troupe failed to receive professional study and could only complete the simplest works. The members just had a certain foundation through a year of training in the troupe, but the team would face the dissolution of the old members and the recruiting of new members. Therefore, it was very difficult to increase the difficulty of the work or improve the performance effect.

\subsubsection{Faculty Strength}

The author sorted out [Table 7] through the contents recorded in the Quarterly Meeting Report of the College Student Art Troupe, through which it can be found that besides the Reception team, the training frequency of each troupe is twice to third times a week, six instructors include four full-time teachers and two part-time teachers with two associate professors, two lecturers and two assistants in the instructor team; except for two instructors in the instrument music troupe, each of the other troupes had an instructor, and one of the instructors of the instrumental music troupe is also responsible for the instruction of the Reception team. In the interview, the author asked the 14 interviewees: "Are you 
satisfied with the arrangement of the existing teachers in the college?" Among the student leaders, the general head of the College Students' Art Troupe, the head of the glee club, the instrumental music troupe, the dance troupe and the recitation troupe were satisfied with the arrangement of teachers, who thought that the teachers had strong professional ability and taught seriously, which could help them improve their professional competence. However, the head of the drama troupe and reception team expressed dissatisfaction. The head of the drama troupe thought that the instructor instructed the work of the troupe as a part-time teacher was instable, the instructor mostly focused on his own work, rather than the instruction of the art troupe The reason why the head of the reception team was not satisfied was that they shared the same instructor with the instrumental music troupe, who was a music performance major and had no experience and foundation of ceremonial work, and could only play a management role, but could not help with the promotion of ceremonial ability. Among the interviewees, the department director and the troupe instructors all expressed dissatisfaction with the existing teachers. They believed that the College Students' Art Troupe had many members with few managers, highperformance requirements with few real returns. The teachers had other jobs besides the instruction work of the College Students' Art Troupe, and the pressure was pretty great.

[Table 7] Faculty Composition Table of the Students' Art Troupe of N Higher Vocational and Technical College

\begin{tabular}{|c|c|c|c|c|c|}
\hline Name & $\begin{array}{c}\text { Teachers } \\
\text { number }\end{array}$ & $\begin{array}{c}\text { Guiding } \\
\text { frequency }\end{array}$ & $\begin{array}{c}\text { Major of guiding } \\
\text { teacher }\end{array}$ & $\begin{array}{c}\text { Title of guiding } \\
\text { teacher }\end{array}$ & Remarks \\
\hline Glee club & 1 (Full-time) & 2 times / week & Music education major & Associate professor & $\begin{array}{c}\text { Daily training before } \\
\text { big events }\end{array}$ \\
\hline $\begin{array}{c}\text { instrumental music } \\
\text { troupe }\end{array}$ & 2 (Full-time) & 3 times / week & $\begin{array}{c}\text { Music performing } \\
\text { major }\end{array}$ & $\begin{array}{c}\text { Lecturer/teaching } \\
\text { assistant }\end{array}$ & $\begin{array}{c}\text { Daily training before } \\
\text { big events }\end{array}$ \\
\hline Dance group & 1 (Full-time) & 3 times / week & Dance major & Lecturers & $\begin{array}{c}\text { Daily training before } \\
\text { big events }\end{array}$ \\
\hline Drama group & 1 (Part-time) & 2 times / week & Drama major & Teaching assistant & $\begin{array}{c}\text { Daily training before } \\
\text { big events }\end{array}$ \\
\hline Reciting team & 1 (Part-time) & 2 times / week & Chinese major & Associate professor & $\begin{array}{c}\text { Daily training before } \\
\text { big events }\end{array}$ \\
\hline Reception team & 1 (Full-time) & Not fixed & $\begin{array}{c}\text { Music performing } \\
\text { major }\end{array}$ & Lecturers & $\begin{array}{c}\text { The same guiding } \\
\text { teacher with music } \\
\text { instrument group }\end{array}$ \\
\hline
\end{tabular}

In the question of "Are you willing to take charge of the work of the college students' art troupe for a long time?" The student leaders and department director expressed their willingness, the student leaders believed that the management of the college students' art troupe had enabled them to exercise their comprehensive ability, and they were willing to work all the time in college. The Department Director expressed that the College Students' Art Troupe was gradually being valued, and he was confident that he could improve the College Students' Art Troupe. But the instructors were reluctant to do so. The main reason was that the instruction works of the College Students' Art Troupe needed to cooperate with the students' rest time. The training was arranged in the evening, and during the daytime they were arranged for other work. Working for over 10 hours a day made them feel tired. The reason why art instructors were unwilling to serve as the instructors of the College Students' Art Troupe for a long time was that they were not paid attention to as non-main professional teachers, had no advantages in professional title evaluation and reward policy, and could not get substantial returns in the case of physical and mental exhaustion. 
[Table 8] Turnover of Art Tutors in the N Higher Vocational and Technical College

\begin{tabular}{|c|c|c|c|}
\hline Year & Employment number & Dimission number & Number of on-the-job art tutor \\
\hline 2014 & 2 & 0 & 4 \\
\hline 2015 & 0 & 0 & 4 \\
\hline 2016 & 1 & 1 & 4 \\
\hline 2017 & 0 & 0 & 4 \\
\hline 2018 & 0 & 0 & 4 \\
\hline 2019 & 1 & 1 & 4 \\
\hline
\end{tabular}

[Table 8] was obtained by the author through the contents of Personnel Registration of College Students' Art Troupe Instructors, through which it can be discovered that $\mathrm{N}$ Higher Vocational and Technical College since 2014 has recruited 4 art instructors, but in the following years 2 instructors resigned, the number of resignations accounts for half of the recruitment, and the number of full-time instructors remains unchanged at 4 in 6 years. The personnel turnover of teachers had a direct impact on the teaching and daily work of the College Students' Art Troupe, and the workload could not be alleviated due to the lack of growth in the number of instructors, so it fell into a vicious circle.

\subsubsection{Activity Scope}

In [Table 9] it was sorted out by the author through the record of the Annual Summary of College Student Art Troupe from 2014 to 2019. As the performance team with the highest art level in the school, the students' art troupe undertakes kinds of performance of the school every year. It can be observed from [Table 9] that the annual performances include performance on the China's Youth Day in May of every year, graduation ceremony performance in June, Freshmen Welcome Performance in October and New Year's Eve performance in December. These are conventional school-level performance activities with many opportunities for performances and rich themes in the school every year.

In response to the interview question, "Are you satisfied with the existing activities?" All 14 interviewees expressed satisfaction. Student leaders believed that the existing activities could meet their desire for the stage. Their troupes in addition to the college's annual fixed performance, but also irregularly to holding special performances, which can enjoy the show themselves. The department director and instructors believed that the existing activities were carefully planned by the team of teachers of the College Students' Art Troupe, which provided a platform for the members of the troupe to show, and also improved the artistic accomplishment of other teachers and students in the college. In response to the question that "What kind of activities do you expect?" 14 interviewees expressed the hope that the activities were not limited to the college, but also out of the campus. From 2014 to 2019 in addition to the three-year Jiangsu Province University Students Art Exhibition, the head of recitation troupe said his team also participated in a school-enterprise cooperation unit performance, other troupe heads said their troupes did not participate in any off-campus performances and exchanges. Although the Students' Art Troupe of Higher Vocational and Technical College did not have much experience of off-campus performances and exchanges, the interviewees all hoped to have a larger stage for exhibition and provide artistic edification for more audiences.

[Table 9] College activities table of the Students' Art Troupe of N Higher Vocational and Technical College

\begin{tabular}{|c|c|c|}
\hline Time & Activities & Service object \\
\hline May & The May 4th Youth Day activities & All the representatives of teachers and students \\
\hline June & Graduation ceremony & All the graduates \\
\hline October & Welcome evening party & All freshman teachers and students \\
\hline December & New Year's party & Teachers and students of the whole school \\
\hline
\end{tabular}


The Characteristics and Flexible Scheme of Students' Art Troupes at Higher Vocational and Technical Colleges in China: A Case Study on the Art Troupe at N Higher Vocational and Technical College

\subsection{Characteristics of the $\mathbf{N}$ Higher Vocational and Technical College}

In this paper, the author uses the method of documentary investigation, observation and interview, follows the principle of "triangle verification", analyzes through the four dimensions of management system, the structure of members, teachers and the scope of activities, and the results show that the Students' Art Troupe of N Higher Vocational and Technical College highlights the following characteristics:

First, Management has begun to develop but is not systematic. After years of operation and management, the students' art troupe of N Higher Vocational and Technical College has begun to take shape. It is found through interviews with group tutors and group leaders and [Table 3] that each group has their own management regulations, a pattern has been formed from election of student cadres to communication between teachers and students, and students and teachers can carry out training and prepare activities and competitions in order in accordance with the existing management system. However, the existing management system is still not perfect, groups carry out management separately, there are no uniform management regulations on the basis of taking the students' art troupe as a whole or taking school as the leadership, and there is no certain constraint capacity in management of the students' art troupe. Existing regulations are prepared by group tutors and group leaders and have not been revised timely along with the development of the Students' Art Troupe. Regulations are not perfect, most regulations are about members' being late or leaving early, and there are no clear contents about financial management of groups, rights and obligations of group members as well as rewards and punishment measures.

Second, Enrollment quality is low, the time in the troupe is short and talent is scarce. The lack of talents in the College Students' Art Troupe is closely related to the system of N Higher Vocational and Technical College. Some of the members of the students' art troupe of N Higher Vocational and Technical College are art students enrolled separately, and some of them are ordinary students. The strength of art students lies in that they can be enrolled by an ideal higher education school with a low college entrance examination result through the art specialty exam, but most students who achieve excellent art performance will choose an undergraduate school instead of a higher vocational and technical college, and most students of higher vocational and technical colleges are from the township where exam-oriented education is mainly conducted and art education is not emphasized. This leads to the lack of talents in the Students' Art Troupe. Because the total educational system of higher vocational and technical colleges is only three years, which is shorter than that of undergraduate colleges and universities, students' time in school is short, so the time in the troupe is also short. The Enrollment quality is low, and the time in the troupe is short, which directly leads to the shortage of talents in the troupe.

Third, The faculty is limited and has high turnover. The school attaches importance to construction of the faculty of the students' art troupe. [Table 7] reveals that during 2014-2019, N Higher Vocational and Technical College has recruited art tutors consecutively. However, during this period, many teachers have been lost, and the total number of art tutors has remained the same. Among tutors of the students' art troupe, the number of lecturers and associate professors accounts for more than one-half of the total number of art tutors. The tutor team has the capacity for art course development and innovation. However, the teacher-student proportion of the students' art troupe is still low, one tutor is in charge of several groups, and tutors only have an art background and lack the management background, so tutors have no theoretical guidance in management of students.

Fourth, There is a diversified campus culture but its branding is not distinct. Along with continuous optimization and development of the students' art troupe, the campus culture life of N Higher Vocational and Technical College has become more colorful. The students' art troupe delivers campus cultures through forms of performance to spread positive spirits. As the students' art troupe gets more exhibition 
platforms on the campus, rich entertainment performance has been provided for more teachers and students outside the Students' Art Troupe. However, the brand influence of the students' art troupe of $\mathrm{N}$ Higher Vocational and Technical College is still not enough to help it walk out the campus. Compared with other excellent art troupes, its competitiveness is weak, it is not known by the public and lacks the opportunity for more exhibition and exchange.

\section{Flexible Scheme of $\mathbf{N}$ Higher Vocational and Technical College}

The characteristics of student art troupes at $\mathrm{N}$ Higher Vocational and Technical College revealed that Chinese higher vocational and technical colleges have problems with their management systems, student sources, teaching abilities, and brand orientation that cause their student art troupes to develop slowly and not achieve ideal results. As a result, these student art troupes are very different from those at fouryear undergraduate educational institutions. Therefore, the author used these reasons to propose corresponding flexible solutions.

First, unify and perfect the management system. The existing systems are only formulated by each branch troupe without specific management knowledge as support, and there is no certain unity. When encountering difficulties in activities, they can neither provide reasonable basis for teachers and students to resolve the difficulties, nor can they be used as a code of conduct to regulate teachers and students to carry out activities. It is necessary to set up a unified system with the college as the unit, and set up specific norms in the system, such as students' rights, obligations, finance, rewards and punishments, emergencies and so on [10][11]. In the use of funds, the department leader should inform the instructors of the total disposable funds per year in advance, and the instructors should make a reasonable plan at the beginning of the year, so as to avoid the confusion of instructors' use of funds in instruction and rationalize the expenses to the greatest extent. In the reward and punishment system, we should clearly establish the reward and punishment system, divide the activities participated by troupe members according to their grades, give awards to troupe members who have made outstanding contributions, better motivate troupe members, and no longer let students take advantage of loopholes. In case of emergencies, the leaders in charge of the departments should coordinate and deal with them from the school level, so as to fundamentally solve the inter-departmental conflicts caused by activities.

Second, improve the quality of students and create a sense of belonging. In the case of low quality of students and short time of college students' art troupe, in order to ensure the normal development of various school activities, teachers can only popularize basic knowledge and reduce the difficulty of works, which can only guarantee the quantity of works a year without guaranteeing the quality of works. In order to improve the quality of the works, we should start from the source of students of the college students' art troupe, including the source of students for the National College Entrance Examination and the school students[12]. In the term of improving the sources of students for the College Entrance Examination. Schools should do more work in the propaganda of College Entrance Examination enrollment, so that more candidates can understand the advantages of the school; contact the training institutions for art examination to publicize together; join key sectors in recruitment brochure and provide better admission policies for art special enrollments. In the aspect of recruiting new students in the school, firstly, the members should actively display the advantages of the college student art troupe and recruit interested students, and secondly, they should communicate with the counselors of the secondary college to mine more students with artistic talent outside the art single enrollment, so that the students with artistic talent in the school can join the College Students' Art Troupe. At the same time, the school should also make the courses of the College Students' Art Troupe universal in the whole school, set up elective courses matching with the College Students' Art Troupe, lay the art enlightenment content on more students, help the College Students' Art Troupe quickly screen out suitable participants from the whole school while improving the comprehensive quality of students. In addition to increasing 
the number of students, but also to avoiding the loss of members. By setting up the common goal and culture of the troupe, students can have collective consciousness, enhance troupe cohesion, customize the exclusive benefits of group building activities, performance observation, lecture listening, psychological counseling and so on [13], so that the College Students' Art Troupe is not only the team of training and performance, but also the spiritual sustenance of students, and find their own sense of belonging and identity.

Third, improve the teaching staff. The existing problems are the insufficient ratio of teachers and students, the heavy workload of teachers, the continuous loss of teachers. The only solution is to recruit new teachers, but this still cannot fundamentally solve the problem of loss of teachers. In order to improve the teaching staff and solve the problem of instructors' insufficient energy of multi-task. firstly, the college should establish independent art education centers so that teachers can devote themselves to the work of college students' art troupes and campus art aesthetic education[14]. Secondly, besides recruiting more professional instructors in the college students' art troupes, teachers in the field of management should also be recruited into the teaching staff to better manage students. At the same time, the college should also provide more training and learning opportunities for the existing teachers, including professional promotion of art and student management, which will help teachers to be handier in the management and instructions of college students' art troupes. Finally, colleges should consider these art instructors in the terms of performance appraisal, professional title evaluation and award evaluation. The college should improve the performance appraisal of teachers and other contents, rather than require teachers to submit payments as obligations, and teachers should be rewarded from the paying out, which can reduce the loss of teachers.

Fourth, Enhance in-campus and off-campus exchange cooperation. The existing activities of the College Students' Art Troupe are limited to the campus, which is not conducive to the development of branding. While the teachers and students on the campus are looking forward to going out of the campus, but they are not dissatisfied with the existing activities, so they have not made changes to go out of the campus. In order to shape the brand of college students' art troupe, we should not be satisfied with the present status[15]. The college has actively declared all kinds of government fund projects, invite excellent groups outside the school to perform on campus, and contact with school-enterprise cooperative units, and other units in the same street and community, and participate in different performances in the form of delivering programs. Besides, the students' art troupes among the peer colleges should exchange more often, learn the excellence of other colleges from the exchanges, and adjust the excellence of other colleges to the students of their own colleges. Through continuous exchanges and cooperation, the college students' art troupes can broaden the performance stage, enhance the popularity and create brand influence.

\section{Conclusions}

In this paper, the author takes the Students' Art Troupe of N Higher Vocational and Technical College as the case, uses the methods of documentary investigation, observation and interview, follows the principle of "triangle verification", and performs multimodal data collection. Analysis of the management system, student structure, faculty strength, the results indicated that activity scope of $\mathrm{N}$ Higher Vocational and Technical College found that students' art troupes at China's higher vocational and technical colleges have the following characteristics: First, Management has begun to develop but is not systematic. Second, Enrollment quality is low, the time in the troupe is short and talent is scarce. Third, The faculty is limited and has high turnover. Fourth, There is a diversified campus culture but its branding is not distinct.

Based on these characteristics, the author presents the corresponding flexible schemes. First, unify and perfect the management system. It is necessary to set up a unified system with the college as the 
unit, and set up specific norms in the system, such as students' rights, obligations, finance, rewards and punishments, emergencies and so on. Second, improve the quality of students and create a sense of belonging. The college should enhance the source of students of the college students' art Troupe by expanding enrollment publicity, and customize the exclusive projects of college students' art troupes to create a sense of belonging of members and avoid brain drain. Third, improve the teaching staff. The college should establish an art management center, expand the enrollment of teachers, provide more opportunities for training, improve the appraisal mechanism of art instructors, improve the lack of teaching staff and solve the problem of loss of teachers. Fourth, Enhance in-campus and off-campus exchange cooperation. To create the chances of going out of the campus and promote the brand influence by declaring all kinds of government fund projects, contacting with school-enterprise cooperative units, sub-district office, peer colleges.

This research is significant because it narrows the gap between the development of students' art troupes at undergraduate institutions and those of vocational and technical colleges in China's higher education system, enhances equality of art education in China's higher education institutions and provides fundamental ideas for further research on students' art troupes at China's higher vocational and technical colleges. Limitations of this research from the perspective of research results, this research presents flexible schemes from the macro aspects, and the specific implementation mechanism and implementation measures need to be further improved. In addition, there are also differences in economic level and art management cognition in different regions of China, so in future research, we can compare the same teams (dance troupes, instrumental music troupe, drama troupes, etc) in different higher vocational and technical colleges, explore deeply, and put forward more targeted development and management for different kinds of college students' art troupes, put forward a more efficient plan for the progress of the art troupe of China's higher vocational and technical colleges, and contribute to the balance of China's higher aesthetic education.

\section{References}

[1] https://www.tsinghua.edu.cn/gqtwyh/index.htm, May 25 (2018)

[2] https://www.art.pku.edu.cn/xsyzt/xsyzjj/index.htm, Apr 1 (2016)

[3] https://tuanwei.nju.edu.cn/bb/56/c24504a375638/page.htm, Nov 1 (2017)

[4] http://www.moe.gov.cn/srcsite/A17/moe_794/moe_628/201810/t20181010_351023.html, Sep 27 (2018)

[5] Y. Y. Leimeng, The Education Function of the Students' Art Troupe in Ordinary Higher Education Schools, Guide for Public Investment, (2019), No.8, pp.250.

[6] J. Z. Li, Influences of College Students' Art Troupe on the Contemporary College Students, Art Evaluation, (2019), No.4, pp.172-173.

[7] Z. Y. Yang, On Construction of College Students' Art Troupe s in Ideological and Political Education, New West, (2019), No.18, pp.132-136, DOI : CNKI:SUN:XXBL.0.2019-18-080

[8] C. He, First Exploration on Integration of the Core Values of Socialism into Cultivation and Construction of Students' Art Troupe s in higher vocational and technical colleges, Yangtze River Series, (2018), No.25, pp.262.

[9] Y. Bai, Exploration and Thinking about Construction and Management of Students' Art Troupe in Higher Education Schools under the New Trend, Think Tank Era, (2018), No.34, pp.117-118.

[10] Y. L. Wang, Research on Management Positioning and Development of Students' Art Troupe s in Ordinary Higher Education Schools, Public Arts, (2017), No.1, pp.217. 
The Characteristics and Flexible Scheme of Students' Art Troupes at Higher Vocational and Technical Colleges in China: A Case Study on the Art Troupe at N Higher Vocational and Technical College

[11] M. Lee, A. Yang, Factors influencing to 21st Century Skill of College Student, Asia-Pacific Journal of Educational Management Research, (2019), Vol.4, No.2, pp.7-14, DOI : CNKI:SUN:XXBL.0.2019-18-080

[12] C. Wang, Innovation of Education Management of Application-Oriented Undergraduate Colleges in Big Data Era, Asia-Pacific Journal of Educational Management Research, (2018), Vol.3, No.2, pp.23-30.

[13] Y. J. Hur, The Impact of the Creative Atmosphere of a Group and Individual Motivation on a University Student's Creative Personality, Asia-Pacific Journal of Educational Management Research, (2016), Vol.1, No.1, pp.23-28.

[14] K. H. Chung, N. S. Lee, S. G. Park, The Effects of the Resilience of University Student on Self-directed Learning Ability and Happiness index, Asia-Pacific Journal of Educational Management Research, (2017), Vol.2, No.1, pp.8388 .

[15] B. K. Cho, Y. C. Choi, H. J. Seo, The Meaning of Sustainable Development as Educational Value Orientation, AsiaPacific Journal of Educational Management Research, (2018), Vol.3, No.1, pp.27-32, DOI:10.21742/AJEMR.2018.3.1.03 